Article

\title{
Structures, Photophysical Properties, and Growth Patterns of Methylurea Coordinated Ni(II) and Mn(II) Complexes
}

\author{
Wenting Wang ${ }^{1,2}$, Zhihuang $\mathrm{Xu}^{2}$, Liwang $\mathrm{Ye}^{2}$, Genbo $\mathrm{Su}^{2}$ and Xinxin Zhuang ${ }^{2, *}$ \\ 1 College of Chemistry, Fuzhou University, Fuzhou 350116, China; wwtshiwojie@163.com \\ 2 Key Laboratory of Optoelectronic Materials Chemistry and Physics, Fujian Institute of Research on the \\ Structure of Matter, Chinese Academy of Sciences, Fuzhou 350002, China; xzh@fjirsm.ac.cn (Z.X.); \\ levakings@163.com (L.Y.); sgb@fjirsm.ac.cn (G.S.) \\ * Correspondence: zxx@fjirsm.ac.cn; Tel.: +86-591-6317-3971
}

Academic Editor: Helmut Cölfen

Received: 24 January 2017; Accepted: 23 February 2017; Published: 28 February 2017

\begin{abstract}
Four coordinated complexes $\mathrm{Mn}_{\mathrm{x}} \mathrm{Ni}_{(1-\mathrm{x})}\left(\mathrm{C}_{2} \mathrm{H}_{6} \mathrm{~N}_{2} \mathrm{O}\right)_{6} \mathrm{SO}_{4}(\mathrm{x}=0,0.33,0.75,0.90)$ were synthesized and characterized. Single-crystal X-ray analysis revealed that the complexes belong to the trigonal crystal family, R-3c space group. Spiral and terraced nucleus growth modes were observed by atomic force microscopy (AFM) in the crystals. Thermogravimetric analysis (TGA) and differential thermal analysis (DTA) measurements showed their excellent thermostability until $200^{\circ} \mathrm{C}$. UV-vis spectra revealed that the transmission peaks of these crystals have a slight bathochromic shift compared to nickel sulfate hexahydrate (NSH), and the transmittance in the UV range increased as the proportion of $\mathrm{Mn}^{2+}$ increased. With their photophysical properties remaining similar, the much higher heat endurance is rendering these crystals better suitable for UV light filter (ULF) applications.
\end{abstract}

Keywords: crystal structure; UV light filter; thermostability; methylurea

\section{Introduction}

Nickel(II) complexes have been widely applied in many regions, for example, catalyzing the synthesis of new compounds [1,2] or being a component of rechargeable batteries [3]. The complexes are also important constituents of ultraviolet light filters (ULFs). ULFs are individual compounds or mixtures to filter most light out and letting one specific wavelength pass. Nickel sulfate hexahydrate $\left(\mathrm{NiSO}_{4} \cdot 6 \mathrm{H}_{2} \mathrm{O}, \mathrm{NSH}\right)$ is the most commonly used crystal in ULFs, as it has a tremendous absorption from $350 \mathrm{~nm}$ to $430 \mathrm{~nm}$ in aqueous solution, with a molar absorptivity of $5.13 \pm 0.03 \mathrm{~mol}^{-1} \cdot \mathrm{dm}^{3} \cdot \mathrm{cm}^{-1}$ at $393 \mathrm{~nm}$ over the range from 0.04 to $0.08 \mathrm{~mol} \cdot \mathrm{cm}^{-3}$ [4]. With a character of high transmission efficiency $(>80 \%)$ to ultraviolet light $(250-340 \mathrm{~nm})$, its potential for acting as a ULF crystal has been exploited. In 1932, NSH crystal was first grown, with its crystal structure reported in detail by Beevers and Lipson [5]. After decades of development, the growth of NSH has been promoted to a larger scale with a lower cost, which leads to a wide usage of NSH in opticalphysics, chemistry, communication, and military [6].

However, NSH crystal starts to dehydrate when the temperature reaches $73{ }^{\circ} \mathrm{C}$ as a result of weak coordination bonds between the central metal and the $\mathrm{O}$ in water ligands [7], which greatly limits its potential applications in some fields, especially under high-temperature conditions. So, efforts have been made during the past decades in order to promote its thermal stability while maintaining its optical properties. In general, the method applied can be grouped into two categories. One is

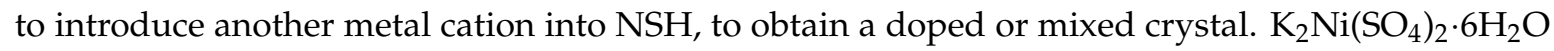
(KNSH) crystal was reported to have a dehydration temperature of $97^{\circ} \mathrm{C}$ in 1998, by Northrop 
Grumman Company [8]. Besides, a number of other crystals were reported as a follow-up, such as $\mathrm{Cs}_{2} \mathrm{Ni}\left(\mathrm{SO}_{4}\right)_{2} \cdot 6 \mathrm{H}_{2} \mathrm{O}$ [9], $\mathrm{FeNi}\left(\mathrm{SO}_{4}\right)_{2} \cdot 12 \mathrm{H}_{2} \mathrm{O}$ [10], $\mathrm{Rb}_{2} \mathrm{Ni}\left(\mathrm{SO}_{4}\right)_{2} \cdot 6 \mathrm{H}_{2} \mathrm{O}$ [11], $\left(\mathrm{NH}_{4}\right)_{2} \mathrm{Co}_{0.17} \mathrm{Ni}_{0.83}$ $\left(\mathrm{SO}_{4}\right)_{2} \cdot 6 \mathrm{H}_{2} \mathrm{O}$ [12], $\mathrm{K}_{2} \mathrm{Co}_{0.1} \mathrm{Ni}_{0.9}\left(\mathrm{SO}_{4}\right)_{2} \cdot 6 \mathrm{H}_{2} \mathrm{O}$ [13], and $\mathrm{K}_{2} \mathrm{Zn}_{\mathrm{x}} \mathrm{Ni}_{1-\mathrm{x}}\left(\mathrm{SO}_{4}\right)_{2} \cdot 6 \mathrm{H}_{2} \mathrm{O}$ [14]. In 2014, guanidine carbonate-doped NSH crystal, whose dehydration temperature was close to $100{ }^{\circ} \mathrm{C}$, had been investigated by Silambarasan et al. [15]. Meena utilized urea/thiourea to induce the growth of $\left(\mathrm{NH}_{4}\right)_{2} \mathrm{Ni}\left(\mathrm{SO}_{4}\right)_{2} \cdot 6 \mathrm{H}_{2} \mathrm{O}$ crystal, which can maintain its weigh until the temperature reaches up to $100{ }^{\circ} \mathrm{C}$ [16]. The other method is to replace its water ligands with other molecules, which have a stronger coordinating ability with $\mathrm{Ni}^{2+}$. $\mathrm{As} \mathrm{Ni}^{2+}$ has an irregular electron configuration (9-17 electron configuration), the interaction between the central atom and the ligand tends to be a covalent bond. The lower the electronegativity of the coordinated atom is, the easier it is to donate an electron pair, which is more conducive to the formation of a stable coordination covalent bond. $\mathrm{Ni}\left(\mathrm{C}_{6} \mathrm{H}_{12} \mathrm{~N}_{4}\right)_{2} \mathrm{SO}_{4} \cdot 4 \mathrm{H}_{2} \mathrm{O}$ crystal, having two of the six water ligands replaced by hexamethylenetetramine, with a better stability and a slight change in absorption band, has been reported recently by Shengmin Gao et al. [17]. Though many methods have been tried, there is still not a dramatic increase in dehydration temperature.

Methylurea is believed to have a strong tendency to bind with divalent metal ions. In 1958, complex $\mathrm{Ni}\left(\mathrm{C}_{2} \mathrm{H}_{6} \mathrm{~N}_{2} \mathrm{O}\right)_{6} \mathrm{SO}_{4}$ (I) was synthesized by Nardelli et al. [18,19]. However, except for crystal cell parameters and physical constants, there are no detailed studies based on this complex. In this paper, three complexes- $\mathrm{Mn}_{\mathrm{x}} \mathrm{Ni}_{(1-\mathrm{x})}\left(\mathrm{C}_{2} \mathrm{H}_{6} \mathrm{~N}_{2} \mathrm{O}\right)_{6} \mathrm{SO}_{4}(\mathrm{x}=0.33$ (II), 0.75 (III), 0.90 (IV))—were synthesized on the basis of (I), and single crystals of (I), (II), (III), and (IV) with centimeter-scale sizes were obtained from aqueous solution by evaporating solvent slowly. The structures of grown crystals were determined by X-ray single-crystal diffraction, and bulk purities were confirmed by powder X-ray diffraction. Metallographic microscope and AFM (atomic force microscopy) were employed to obtain the information on micro-aspects. UV-vis spectra were obtained to study their photophysical properties. Differential thermal analysis (DTA) and thermogravimetric analysis (TGA) measurements showed their excellent stability until $200^{\circ} \mathrm{C}$, indicating the pronounced enhancement in heat endurance compared to NSH.

\section{Results and Discussion}

\subsection{Structures of (II), (III), and (IV)}

The structure of complex (I) crystallizes in the trigonal space group R-3c with $a=b=10.93(2) \AA$, $c=40.19(8) \AA$, and $V=4206.8(6) \AA^{3}$, which was reported by Nardelli et al. in 1958 [18]. Crystal data, data collection, and structure refinement details for (II), (III), and (IV) are summarized in Table 1. The structures were solved by direct methods and refined by the full matrix least-squares method using Olex2 and SHELXL [20,21]. In one repeating unit, $\mathrm{M}\left(\mathrm{Ni}^{2+} / \mathrm{Mn}^{2+}\right)$ serves as the coordinate center, surrounded by six $\mathrm{O}$ atoms from the carbonyl group of methylurea. In general, these six $\mathrm{O}$ atoms coordinate with the center by bonds of similar length, giving an octahedral structure. As they are in a similar chemical environment, the $\mathrm{O}$ atoms are equal to each other. The center atom $\mathrm{M}$ and the two $\mathrm{O}$ atoms - which are opposite to each other-are localized on a line, as the angle between them is approaching $180^{\circ}$ (Figures 1 and 2a). Selected bond lengths and bond angles are listed in Table 2. As shown in Figure 2a,c, the hydrogen bond $\mathrm{N}-\mathrm{H}$... O (between an $\mathrm{O}$ atom of one methylurea and

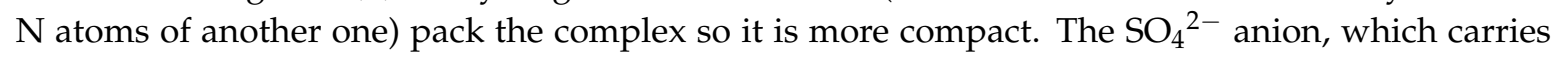
negative charge to balance the positive charge, has a tetrahedral geometry and is associated with the octahedral unit by N-H...O hydrogen bond. The hydrogen bond lengths and bond angles of (II), (III), and (IV) are listed in Tables 3-5. The unit cell is shown in Figure 2b; the C, N, and H atoms are omitted for clarity. Complexes(III) and (IV) have identical structures to (II), except the increasement of the $\mathrm{M}-\mathrm{O}$ bond length and the increased proportion of $\mathrm{Mn}^{2+}$, which has a larger ionic radius than $\mathrm{Ni}^{2+}$. The hydrogen bonds in these three crystal structures play a crucial role in raising the decomposition temperature. Compared to $\mathrm{NSH}$, whose hydrogen bonds only show up between $\mathrm{H}_{2} \mathrm{O}$ ligands and 
the $\mathrm{SO}_{4}{ }^{2-}$ anion, there are associations between the $\mathrm{H}$ in the amino group and the $\mathrm{O}$ in the carbonyl group of different methylurea ligands. The complexes are packed more tightly, as a result of these intramolecular attractions. To break up the structure of these complexes, the energy for disassociation of the hydrogen bonds has to be applied, which could lead to an increasement of thermal stability.

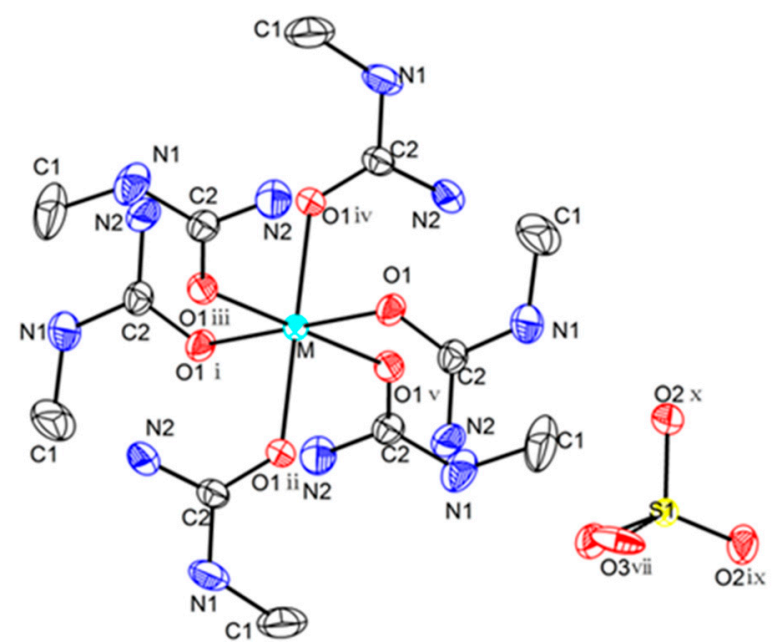

Figure 1. The coordination environment of the $\mathrm{M}\left(\mathrm{Ni}^{2+} / \mathrm{Mn}^{2+}\right)$ in (I), (II), (III), and (IV), shown with $30 \%$ probability displacement ellipsoids. $\mathrm{H}$ atoms have been omitted for clarity.

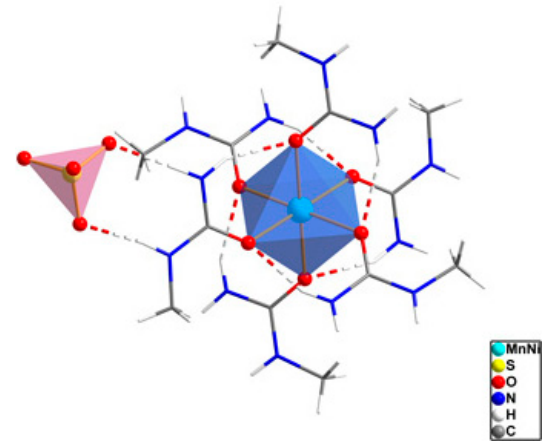

(a)

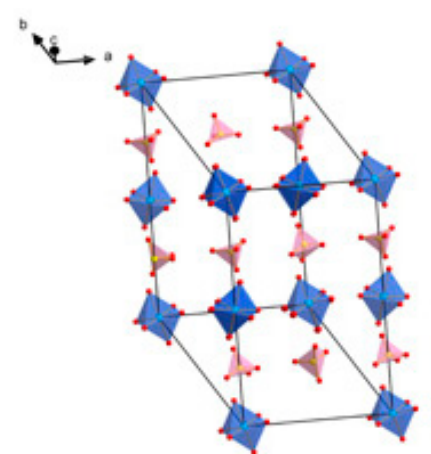

(b)

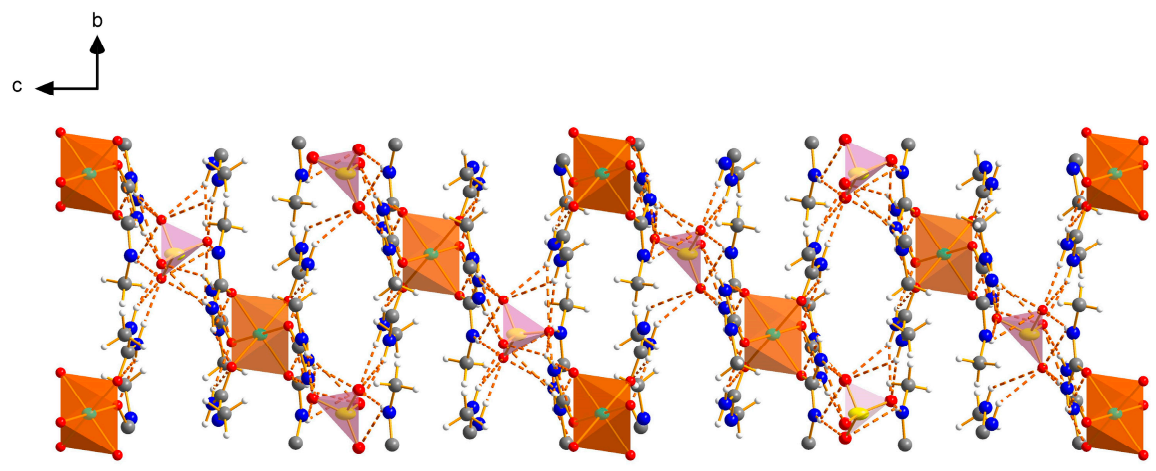

(c)

Figure 2. (a) The coordination polyhedral around $\mathrm{Ni}^{2+} / \mathrm{Mn}^{2+}$ in (I), (II), (III), and (IV); (b) packing diagram for (I), (II), (III), and (IV); C, H, N atoms have been omitted for clarity; (c) packing diagram for (I), (II), (III), and (IV); viewed along [100]. 
Table 1. Experimental details.

\begin{tabular}{|c|c|c|c|}
\hline Crystal Data & (II) & (III) & (IV) \\
\hline CCDC No. & 1511167 & 1511166 & 1515437 \\
\hline Chemical formula & $\mathrm{C}_{12} \mathrm{H}_{36} \mathrm{Mn}_{0.33} \mathrm{~N}_{12} \mathrm{Ni}_{0.67} \mathrm{O}_{6} \cdot \mathrm{O}_{4} \mathrm{~S}$ & $\mathrm{C}_{12} \mathrm{H}_{36} \mathrm{Mn}_{0.75} \mathrm{~N}_{12} \mathrm{Ni}_{0.25} \mathrm{O}_{6} \cdot \mathrm{O}_{4} \mathrm{~S}$ & $\mathrm{C}_{12} \mathrm{H}_{36} \mathrm{Mn}_{0.90} \mathrm{~N}_{12} \mathrm{Ni}_{0.10} \mathrm{O}_{6} \cdot \mathrm{O}_{4} \mathrm{~S}$ \\
\hline$M_{\mathrm{r}}$ & 598.04 & 596.47 & 595.53 \\
\hline Crystal system, space group & Trigonal, $R-3 c$ & Trigonal, $R-3 c$ & Trigonal, $R-3 c$ \\
\hline Temperature $(\mathrm{K})$ & 293 & 293 & 293 \\
\hline$a, c(\AA)$ & $10.9919(7), 40.634(5)$ & $11.0402(5), 40.696(4)$ & $11.0845(6), 40.805(4)$ \\
\hline$V\left(\AA^{3}\right)$ & $4251.7(7)$ & $4295.7(6)$ & $4341.8(7)$ \\
\hline $\mathrm{Z}$ & 6 & 6 & 6 \\
\hline Radiation type & Mo $K \alpha$ & Mo $K \alpha$ & Mo $K \alpha$ \\
\hline$\mu\left(\mathrm{mm}^{-1}\right)$ & 0.75 & 0.65 & 0.61 \\
\hline Crystal size (mm) & $0.18 \times 0.16 \times 0.12$ & $0.20 \times 0.20 \times 0.20$ & $0.18 \times 0.16 \times 0.14$ \\
\hline Diffractometer & Bruker P4 diffractometer & Bruker P4 diffractometer & Bruker P4 diffractometer \\
\hline Absorption correction & Multi-scan Crystal Clear & Multi-scan Crystal Clear & Multi-scan Crystal Clear \\
\hline$T_{\min }, T_{\max }$ & $0.740,1.000$ & $0.752,1.000$ & $0.840,1.000$ \\
\hline No. of measured, independent and observed $[I>2 \sigma(I)]$ reflections & $8948,964,875$ & $9215,1090,932$ & $9929,1090,946$ \\
\hline$R_{\text {int }}$ & 0.037 & 0.039 & 0.046 \\
\hline$(\sin \theta / \lambda)_{\max }\left(\AA^{-1}\right)$ & 0.624 & 0.649 & 0.648 \\
\hline$R\left[F^{2}>2 \sigma\left(F^{2}\right)\right], w R\left(F^{2}\right), S$ & $0.042,0.118,1.10$ & $0.043,0.120,1.07$ & $0.048,0.139,1.08$ \\
\hline Data/restraints/parameters & $964 / 9 / 63$ & $1090 / 0 / 63$ & $1090 / 0 / 63$ \\
\hline $\mathrm{H}$-atom treatment & H-atom parameters constrained & $\mathrm{H}$-atom parameters constrained & $\mathrm{H}$-atom parameters constrained \\
\hline$\Delta \varrho_{\max }, \Delta \varrho_{\min }\left(\mathrm{e} \cdot \AA^{-3}\right)$ & $0.74,-0.53$ & $0.58,-0.47$ & $0.63,-0.42$ \\
\hline
\end{tabular}


Table 2. Selected geometric parameters $\left(\AA^{\circ},{ }^{\circ}\right)$ for (II), (III), and (IV).

\begin{tabular}{cccc}
\hline Bond Lengths and Bond Angles & (II) & (III) & (IV) \\
\hline M-O1 & $2.0921(14)$ & $2.1366(13)$ & $2.1706(14)$ \\
M-O1 ${ }^{\text {i }}$ & $2.0923(14)$ & $2.1366(13)$ & $2.1708(14)$ \\
M-O1 ii & $2.0923(15)$ & $2.1365(13)$ & $2.1708(14)$ \\
M-O1 iii & $2.0923(14)$ & $2.1366(13)$ & $2.1708(14)$ \\
M-O1 iv & $2.0921(14)$ & $2.1366(13)$ & $2.1706(14)$ \\
M-O1 v & $2.0921(14)$ & $2.1365(13)$ & $2.1706(14)$ \\
O1-C1 & $1.256(3)$ & $1.255(2)$ & $1.258(2)$ \\
N1-C1 & $1.332(3)$ & $1.329(3)$ & $1.332(3)$ \\
N1-C2 & $1.441(4)$ & $1.432(4)$ & $1.439(4)$ \\
N2-C1 & $1.328(3)$ & $1.335(3)$ & $1.333(3)$ \\
O1 ${ }^{\text {ii-M-O1 }}$ v & 180.0 & 180.0 & 180.0 \\
O1 ${ }^{\text {i }-M-O 1 ~}$ & $179.99(9)$ & 180.0 & 180.0 \\
O1 ${ }^{\text {iv }-M-O 1 ~}{ }^{\text {iii }}$ & $179.990(1)$ & $180.00(7)$ & 180.0 \\
\hline
\end{tabular}

Symmetry codes: ${ }^{\mathrm{i}}-\mathrm{x}+4 / 3,-\mathrm{y}+2 / 3,-\mathrm{z}+2 / 3 ;{ }^{\mathrm{ii}} \mathrm{y}+1 / 3,-\mathrm{x}+\mathrm{y}+2 / 3,-\mathrm{z}+2 / 3 ;{ }^{\text {iii }} \mathrm{x}-\mathrm{y}+1 / 3, \mathrm{x}-1 / 3$, $-z+2 / 3 ;^{i v}-x+y+1,-x+1, z^{v}-y+1, x-y$,

Table 3. Hydrogen-bond geometry $\left(\AA^{\circ},^{\circ}\right)$ for (II).

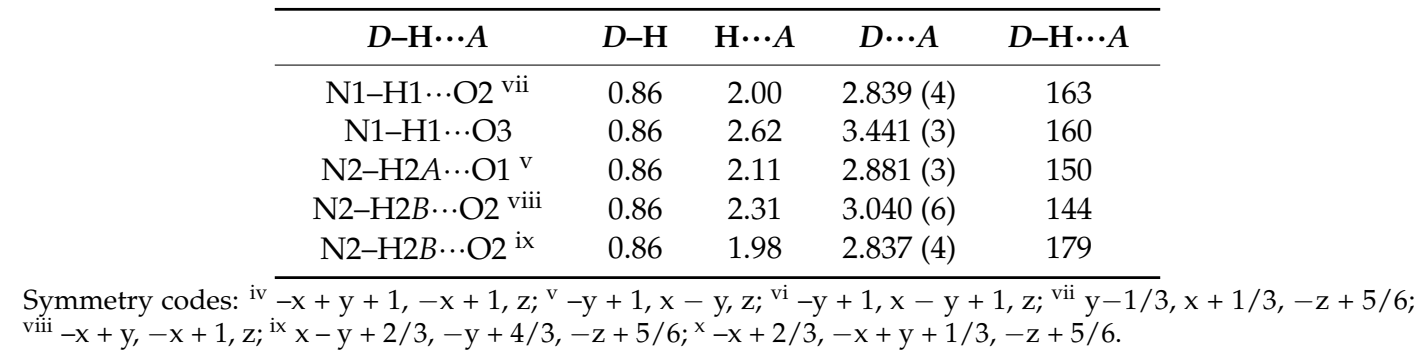

Table 4. Hydrogen-bond geometry $\left(\AA^{\circ}{ }^{\circ}\right)$ for (III).

\begin{tabular}{|c|c|c|c|c|}
\hline$D-\mathrm{H} \cdots A$ & $D-\mathrm{H}$ & $\mathrm{H} \cdots A$ & $D \cdots A$ & $D-\mathbf{H} \cdots A$ \\
\hline $\mathrm{N} 1-\mathrm{H} 1 \cdots \mathrm{O} 2^{x}$ & 0.86 & 1.99 & $2.831(4)$ & 164 \\
\hline 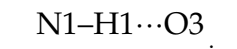 & 0.86 & 2.63 & $3.450(3)$ & 159 \\
\hline $\mathrm{N} 2-\mathrm{H} 2 A \cdots \mathrm{O} 1^{\text {iv }}$ & 0.86 & 2.14 & $2.916(2)$ & 151 \\
\hline $\mathrm{N} 2-\mathrm{H} 2 B \cdots \mathrm{O} 2$ & 0.86 & 2.31 & $3.045(5)$ & 143 \\
\hline $\mathrm{N} 2-\mathrm{H} 2 B \cdots \mathrm{O} 2^{\mathrm{ix}}$ & 0.86 & 1.98 & $2.835(4)$ & 179 \\
\hline
\end{tabular}

Symmetry codes: ${ }^{\text {iii }} \overline{x-y+1 / 3, x-1 / 3,-z+2 / 3^{\text {iv }}-x+y+1,-x+1, z^{\mathrm{v}}-y+1, x-y, z}{ }^{\text {vi }}-y+1, x-y+1, z$; vii $y-1 / 3, x+1 / 3,-z+5 / 6 ;^{\text {viii }}-x+y,-x+1, z ;^{\text {ix }} x-y+2 / 3,-y+4 / 3,-z+5 / 6 ;^{x}-x+2 / 3,-x+y+1 / 3$, $-z+5 / 6$.

Table 5. Hydrogen-bond geometry $\left(\AA,^{\circ}\right)$ for (IV).

\begin{tabular}{|c|c|c|c|c|}
\hline$D-\mathbf{H} \cdots A$ & $D-\mathbf{H}$ & $\mathbf{H} \cdots A$ & $D \cdots A$ & $D-\mathrm{H} \cdots A$ \\
\hline 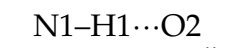 & 0.86 & 2.00 & $2.832(4)$ & 164 \\
\hline $\mathrm{N} 1-\mathrm{H} 1 \cdots \mathrm{O} 3{ }^{\text {vii }}$ & 0.86 & 2.64 & $3.457(3)$ & 160 \\
\hline $\mathrm{N} 2-\mathrm{H} 2 A \cdots \mathrm{O} 1^{\text {iv }}$ & 0.86 & 2.16 & $2.944(3)$ & 151 \\
\hline $\mathrm{N} 2-\mathrm{H} 2 B \cdots \mathrm{O} 2^{\mathrm{x}}$ & 0.86 & 2.31 & $3.039(5)$ & 143 \\
\hline $\mathrm{N} 2-\mathrm{H} 2 B \cdots \mathrm{O} 2{ }^{\mathrm{vi}}$ & 0.86 & 1.98 & $2.836(4)$ & 179 \\
\hline
\end{tabular}

Powder X-ray diffraction (PXRD) experiments were also carried out to confirm the phase purity of the complexes (Figure 3). The positions of the peaks calculated by PXRD are fully overlapped with 
the ones measured by single-crystal diffraction (XRD), illustrating the fact that the synthesized sample is of high purity. The positions of diffraction peaks show a shift to low angles, corresponding with the fact that the cell parameters of the title crystals increased with the enhancement of proportion of $\mathrm{Mn}^{2+}$.

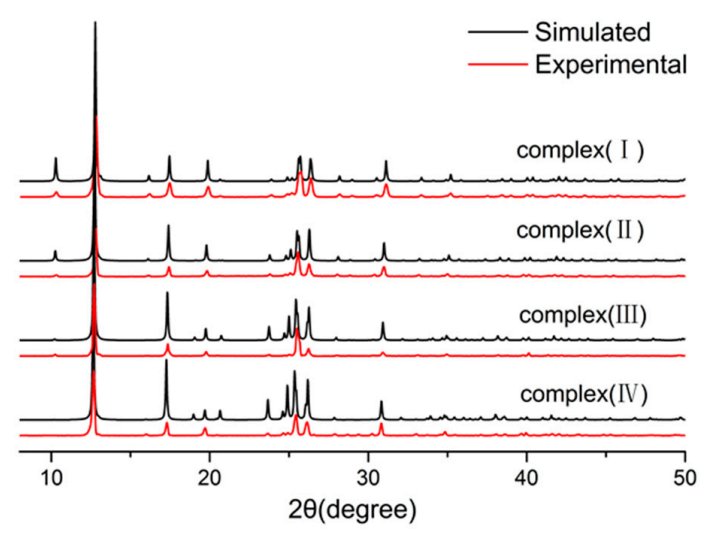

Figure 3. Powder X-ray diffraction patterns for (I), (II), (III), and (IV).

\subsection{Dislocation Etch Pit and Growth Steps}

Crystal plane indices were indexed according to the crystal edge angles. A schematic diagram of crystal planes is shown in Figure 4. The $\left(\begin{array}{llll}0 & 0 & 0 & 1\end{array}\right)$ planes of the crystals were corroded by ultrapure water directly for $2 \mathrm{~min}$, and were observed by a Leica DM2500 metallographic microscope. The photos of dislocation etch pits for (I), (II), (III), and (IV) are shown in Figure 5a-d, respectively. All dislocation etch pits were trigonal. $\mathrm{A} \mathrm{L}^{3}$ rotation axis and three vertical symmetry planes in the etch pits could be easily observed, which is in agreement with the fact that these crystals crystallize in a trigonal crystal system. The pits in $\mathrm{Mn}^{2+}$-containing crystals ((II), (III), and (IV)) are found to be deeper and smaller than those of (I), because of the enhancement of solubility along with the rising proportion of $\mathrm{Mn}^{2+}$. The $\{01-14\}$ planes were split, and the cleavage planes of (III) were studied by AFM, in order to have a better understanding of growth steps. Growth hillocks of screw dislocation were observed on $\{01-14\}$ planes (Figure 6a). The shape of the growth hillock is elliptic, indicating an anisotropic morphology in growth. Growth steps on the left side of hillock are base steps, but the right ones are accumulated, which is considered to be caused by solute transport effect. The dislocation outcrop of growth hillock shown in Figure $6 a, b$ was covered by growth layers of a terraced nucleus, which is the step source of further nucleating. New nucleus formed on this basis, and grew layer upon layer, finally resulting in an island morphology [22-24]. As shown in Figure 6c, the vertical height of the

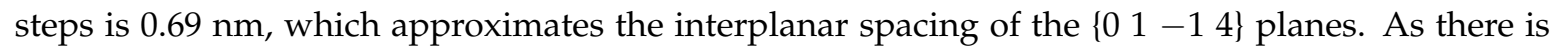
a sufficient growth component surrounding $\{01-14\}$ planes, it is easier to form step here, and the area of the crystal face is the smallest with a high tolerance to impurities, resulting in a relatively straight step flow.

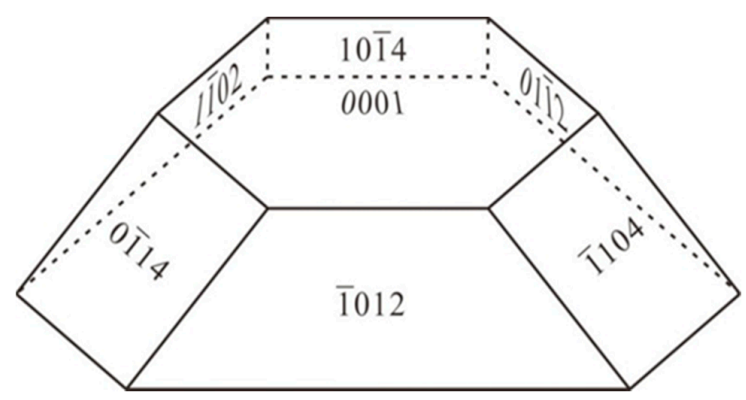

Figure 4. Schematic diagram and crystal plane indices for (I), (II), (III), and (IV). 


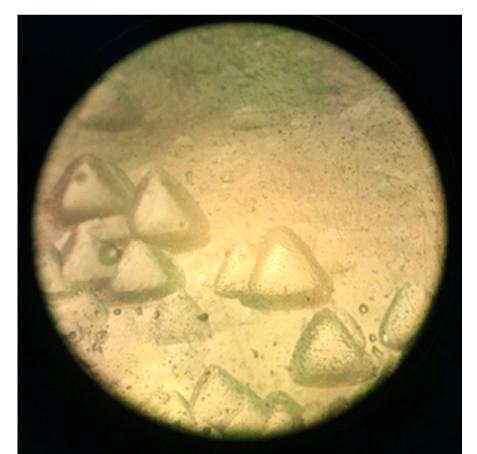

(a)

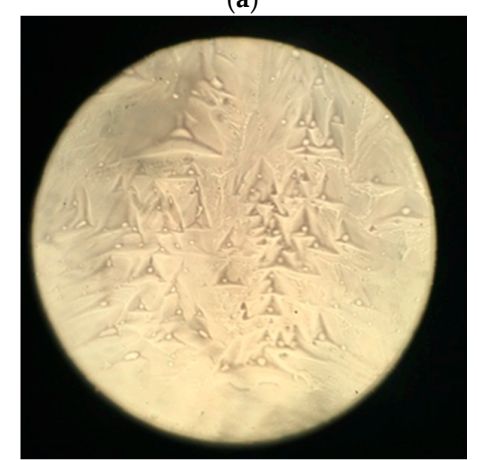

(c)

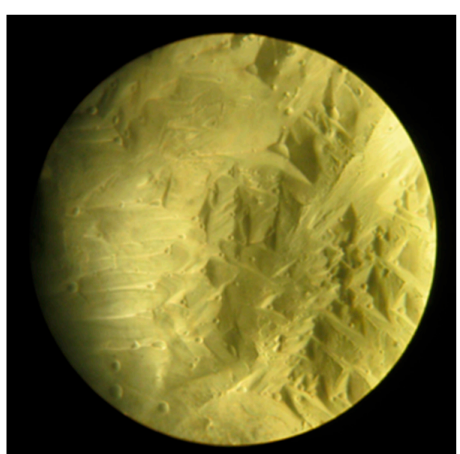

(b)

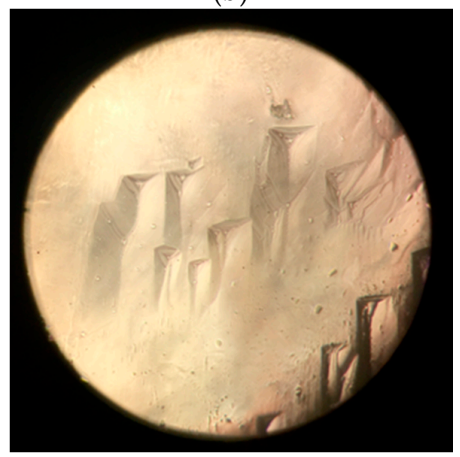

(d)

Figure 5. Dislocation etch pits for (a) (I), (b)(II), (c) (III), and (d) (IV).

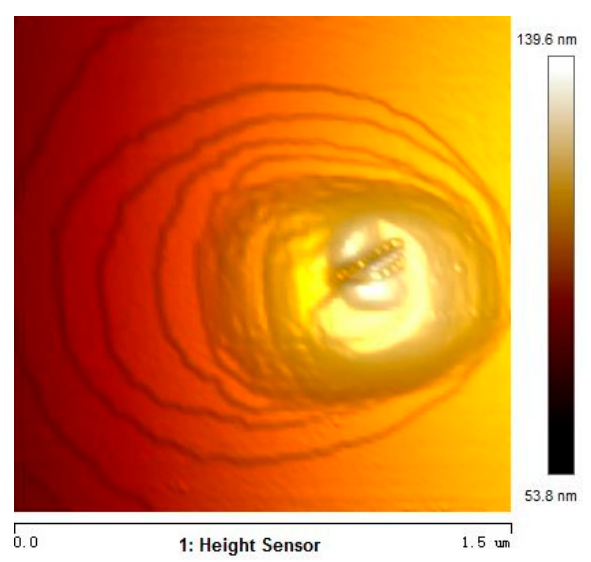

(a)

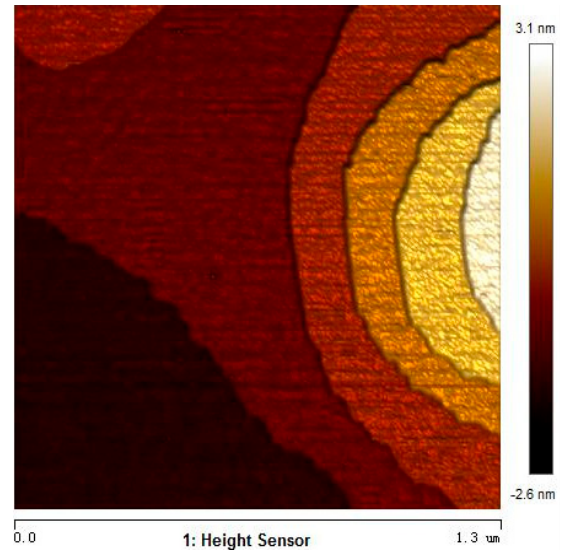

(b)

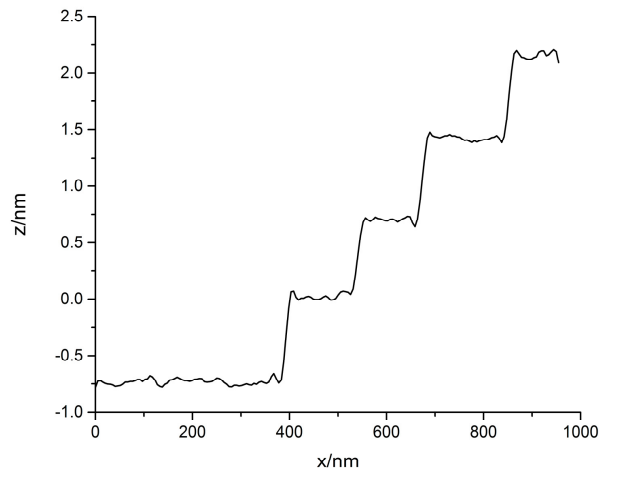

(c)

Figure 6. (a) Atomic force microcopy (AFM) images of growth hillock of $\{01-14\}$ planes; (b) magnified AFM images of growth steps of $\left\{\begin{array}{lll}0 & 1-1 & 4\end{array}\right\}$ planes; (c) growth steps flow curve of $\left\{\begin{array}{lll}0 & 1-1 & 4\end{array}\right\}$ planes. 


\subsection{TGA and DTA Analysis}

Thermal gravimetric analysis (TGA) and differential thermal analysis (DTA) measurements were done with STA449C-QMS403C instrument at a heating rate of $10^{\circ} \mathrm{C} / \mathrm{min}$ from $40^{\circ} \mathrm{C}$ to $800{ }^{\circ} \mathrm{C}$ under $\mathrm{N}_{2}$. As shown in Figure 7, crystals (I), (II), (III), and (IV) start to decompose at $208^{\circ} \mathrm{C}, 20{ }^{\circ} \mathrm{C}, 195^{\circ} \mathrm{C}$, and $183{ }^{\circ} \mathrm{C}$, respectively, far higher than the decomposition temperature of $\mathrm{NSH}\left(73^{\circ} \mathrm{C}\right)$. All the DTA measurements of these three crystals show a peak above $200{ }^{\circ} \mathrm{C}$, respectively, indicating an excellent thermostability. Both TGA and DTA analysis reach the same conclusion that the replacement of water ligands in NSH by methylurea enhanced its heat endurance to a great extent. The higher degradation temperature is predictable, because of the increase of binding energy between the central metal and ligands.

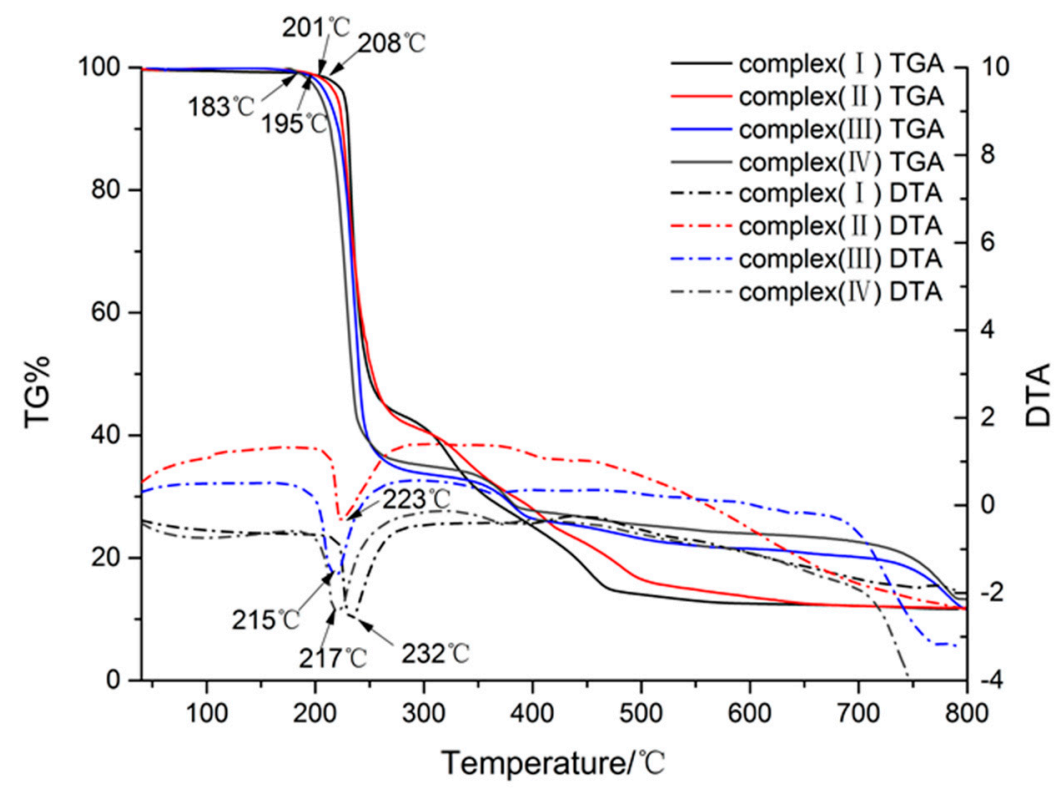

Figure 7. Thermogravimetric analysis (TGA) and differential thermal analysis (DTA) curves for (I), (II), (III), and (IV).

\subsection{Photophysical Properties}

UV absorption spectra were recorded with a PE-Lambda 950 spectrometer by testing the samples (with a thickness of $3 \mathrm{~mm}$ ) in the range from 200 to $1000 \mathrm{~nm}$. As shown in Figure 8, compounds (I), (II), (III), and (IV) have similar photophysical properties, showing peaks at $372 \mathrm{~nm}, 466 \mathrm{~nm}$, and $836 \mathrm{~nm}$. The decent absorption, which covers most of the spectra, is mainly caused by $\mathrm{Ni}^{2+}$, leading to the result that more light can pass through the crystals when the portion of $\mathrm{Mn}^{2+}$ increases. Compared to NSH crystal, the transmittance of all three crystals has a slight bathochromic shift $(10 \mathrm{~nm})$. This phenomenon can be explained by the fact that methylurea is a relatively electron sufficient molecule, compared to water. The two electron-donating groups, amino and methylamino, are associated with the carbonyl group, making the $\mathrm{O}$ more electron-rich compared to the one in the water molecule, leading to a diminution of the energy difference between bonding molecular orbitals (MOs) and nonbonding MOs, thus, resulting in a bathochromic shift of the transmittance spectra. Still, the three newly synthesized complexes have a very low absorption, only at UV range (200-395 nm), allowing UV light to pass through selectively. With their photophysical properties remaining similar, the higher heat-endurance makes these crystals better substitutions for NSH. 


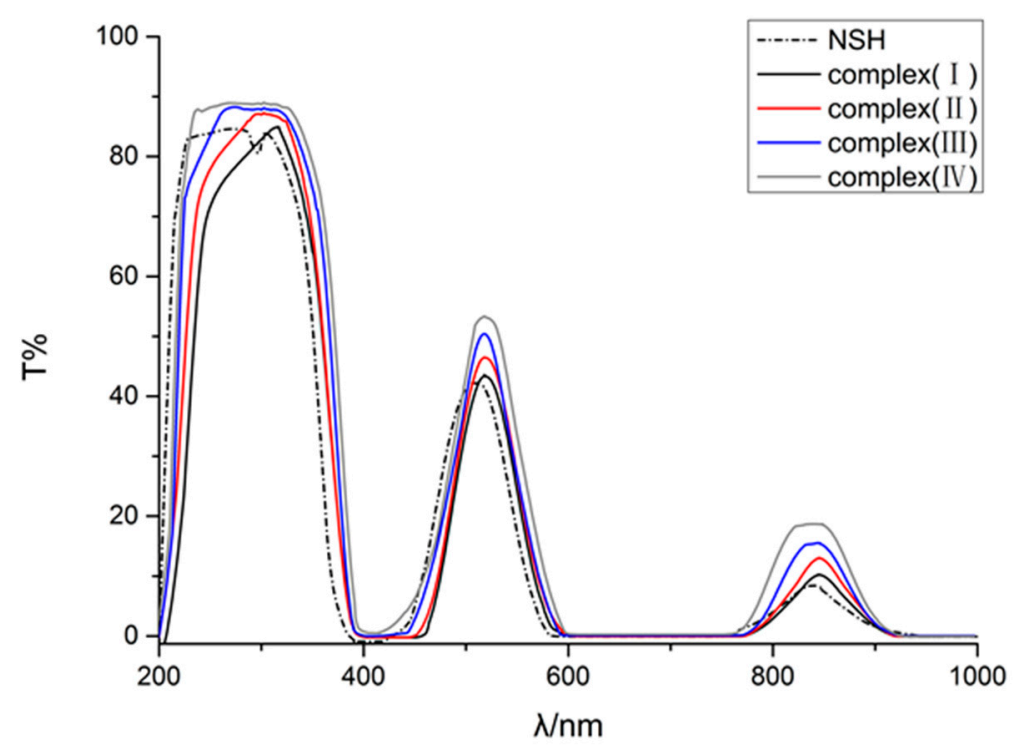

Figure 8. Transmission spectra for (I), (II), (III), and (IV).

\section{Experimental}

\section{Synthesis and Crystallization}

Nickel sulphate (AR), manganese sulphate (AR), and methylurea (AR) were used without further purification. Thermal gravimetric analysis (TGA) and differential thermal analysis (DTA) measurements were done with STA449C-QMS403C instrument at a heating rate of $10^{\circ} \mathrm{C} / \mathrm{min}$ from $40{ }^{\circ} \mathrm{C}$ to $800{ }^{\circ} \mathrm{C}$ under $\mathrm{N}_{2}$. Absorption spectra were recorded with PE-Lambda 950 spectrometer by testing samples with a thickness of $3 \mathrm{~mm}$ in the range from 200 to $1000 \mathrm{~nm}$.

Complexes (I), (II), (III), and (IV) were synthesized in accordance of the following reaction:

$$
(1-\mathrm{x}) \mathrm{NiSO}_{4} \cdot 6 \mathrm{H}_{2} \mathrm{O}+\mathrm{xMnSO} \mathrm{H}_{4} \cdot \mathrm{H}_{2} \mathrm{O}+6 \mathrm{C}_{2} \mathrm{H}_{6} \mathrm{~N}_{2} \mathrm{O} \rightarrow \mathrm{Mn}_{\mathrm{x}} \mathrm{Ni}_{(1-\mathrm{x})} \mathrm{SO}_{4} \cdot 6 \mathrm{C}_{2} \mathrm{H}_{6} \mathrm{~N}_{2} \mathrm{O}+\mathrm{H}_{2} \mathrm{O}
$$

In general, stoichiometric nickel sulphate, manganese sulphate and methylurea were dissolved in ultrapure water, respectively, and the solutions were mixed after filtration by a microporous filtering film. The mixed filtrate was stirred for $7 \mathrm{~h}$ at $60^{\circ} \mathrm{C}$ in a beaker and was allowed to evaporate slowly at the same temperature. After 1week, regular crystals with good optical properties were attained.

The grown crystals are shown in Figure 9. Inductively coupled plasma (ICP) revealed the proportions of $\mathrm{Mn}^{2+} / \mathrm{Ni}^{2+}$ in complexes (II), (III), and (IV) are 0.33:0.67, 0.75:0.25, and 0.90:0.10, respectively. Anal. calcd. (\%) for $\mathrm{C}_{12} \mathrm{H}_{36} \mathrm{~N}_{12} \mathrm{O}_{10} \mathrm{SNi}$ (599.30): $\mathrm{C}, 24.05 ; \mathrm{H}, 6.05 ; \mathrm{N}, 28.04$. Found (\%): $\mathrm{C}$, 24.04; $\mathrm{H}, 5.98 ; \mathrm{N}$, 27.75. Anal. calcd. (\%) for $\mathrm{C}_{12} \mathrm{H}_{36} \mathrm{~N}_{12} \mathrm{O}_{10} \mathrm{~S} \mathrm{Ni}_{0.33} \mathrm{Mn}_{0.67}$ (598.04): C, 24.10; $\mathrm{H}, 6.07$; $\mathrm{N}$, 28.11. Found (\%): C, 24.08; H, 6.02; N, 27.75. Anal. calcd. (\%) for $\mathrm{C}_{12} \mathrm{H}_{36} \mathrm{~N}_{12} \mathrm{O}_{10} \mathrm{SNi}_{0.25} \mathrm{Mn}_{0.75}$ (596.47): C, 24.16; H, 6.08; N, 28.19. Found (\%): C, 24.14; H, 6.02; N, 27.78.Anal.calcd. (\%) for $\mathrm{C}_{12} \mathrm{H}_{36} \mathrm{~N}_{12} \mathrm{O}_{10} \mathrm{SNi}_{0.10} \mathrm{Mn}_{0.90}$ (595.53): C, 24.20; H, 6.09; N, 28.23. Found (\%): $\mathrm{C}, 24.16 ; \mathrm{H}, 6.03 ; \mathrm{N}, 27.80$. Selected IR data $\left(\mathrm{KBr}, \mathrm{cm}^{-1}\right)$ : $3424(\mathrm{~m}), 3322(\mathrm{~m}), 2937(w), 2884(w), 1650(\mathrm{~s}), 1594(\mathrm{~m}), 1575(\mathrm{~m}), 1416(\mathrm{~m})$, $1369(m), 1126(m), 771(w), 621(w), 528(w)$. In the IR spectrum, a pointed peak occurs at $1650 \mathrm{~cm}^{-1}$ because of $\mathrm{C}=\mathrm{O}$ stretching vibration in the amide. Two peaks at $3424 \mathrm{~cm}^{-1}$ and $3322 \mathrm{~cm}^{-1}$ are the characteristic peaks of $\mathrm{N}-\mathrm{H}$ stretching vibrations. 


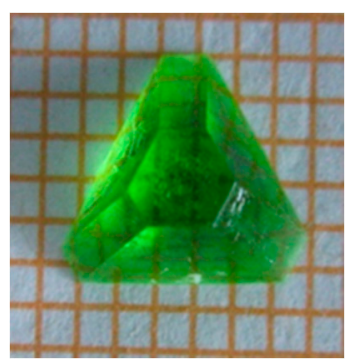

(a)

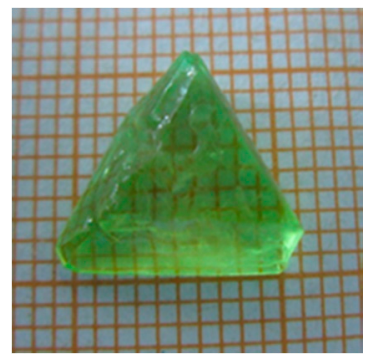

(b)

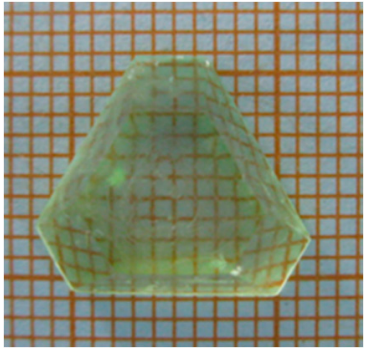

(c)

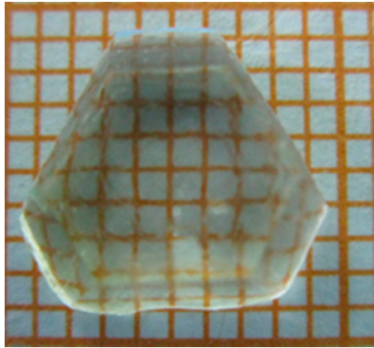

(d)

Figure 9. Photographs of crystals (a) (I), (b) (II), (c) (III), and (d) (IV).

\section{Conclusions}

In summary, four complexes, $\mathrm{Mn}_{x} \mathrm{Ni}_{(1-x)}\left(\mathrm{C}_{2} \mathrm{H}_{6} \mathrm{~N}_{2} \mathrm{O}\right){ }_{6} \mathrm{SO}_{4}(\mathrm{x}=0,0.33,0.75,0.90)$, were synthesized and characterized. XRD revealed the title crystals belong to the trigonal system, R-3c space group. Extra intramolecular hydrogen bonds make the complexes more stable than NSH. Two growth patterns, spiral or terraced nucleus, were observed by AFM on $\left\{\begin{array}{lll}1 & -1 & 4\end{array}\right\}$ planes, and the height of growth steps corresponds with plane spacing. TGA and DTA measurements proved that the heat endurance could be enhanced to a great extend (upto $200{ }^{\circ} \mathrm{C}$ ) by replacing all six water ligands of NSH with methylurea. UV-vis spectra revealed the transmission peaks of title crystals have a slight bathochromic shift $(10 \mathrm{~nm})$, compared to NSH. With their photophysical properties remaining similar, the much higher heat endurance makes these crystals suitable for ULF applications.

Supplementary Materials: The following are available online at www.mdpi.com/2073-4352/7/3/68/s1, Table S1: Bond lengths $(\AA)$ and angles $\left(^{\circ}\right)$ for (II), Table S2: Torsion angles $\left(^{\circ}\right)$ for (II), Table S3:Bond lengths $(\AA)$ and angles $\left({ }^{\circ}\right)$ for (III), Table S4:Torsion angles $\left(^{\circ}\right)$ for (III), Table S5: Bond lengths ( $(\AA)$, and angles $\left({ }^{\circ}\right)$ for (IV), Table S6: Torsion angles $\left(^{\circ}\right)$ for $(\mathrm{IV})$.

Author Contributions: Wenting Wang conceived, designed, performed the experiments, analyzed the data and wrote the paper; Zhihuang $\mathrm{Xu}$ and Liwang Ye contributed materials and analysis tools; Genbo Su and Xinxin Zhuang gave guidance and advice.

Conflicts of Interest: The authors declare no conflict of interest.

\section{References}

1. Ovcharenko, V.; Kuznetsova, O.; Fursova, E.; Romanenko, G.; Bogomyakov, V.A. New method for the synthesis of heterospin complexes. Crystals 2015, 5, 634-649. [CrossRef]

2. Mautner, F.A.; Fischer, R.C.; Spell, M.; Acevedo, A.R.; Tran, D.H.; Massoud, S.S. Metal(II) complexes of compartmental polynuclear schiff bases containing phenolate and alkoxy groups. Crystals 2016, 6, 91. [CrossRef]

3. Young, K.H. Research in nickel/metal hydride batteries 2016. Batteries 2016, 2, 31. [CrossRef]

4. Mathpal, S.; Kandpal, N.D. Colorimetric estimation of Ni(II) Ions in aqueous solution. J. Chem. 2009, 6, 445-448. [CrossRef]

5. Beevers, C.A.; Lipson, H. The Crystal Structure of Nickel Sulphate Hexahydrate, $\mathrm{NiSO}_{4} \cdot 6 \mathrm{H}_{2} \mathrm{O}$. Z. Krist. 1935, 91, 157-169. [CrossRef]

6. Duraikkan, V.; Bahadur, S.A.; Athimoolam, S. Crystal Growth and Characterization of Potassium Manganese Nickel Sulphate Hexahydrate-A New UV Filter. J. Min. Mater. Charact. Eng. 2012, 11, 1121-1125. [CrossRef]

7. Koga, N.; Tanaka, H. Thermoanalytical and microscopic investigations of the thermal dehydration of $\alpha$-nickel(II) sulphate hexahydrate. J. Therm. Anal. 1993, 40, 1165-1172. [CrossRef]

8. Singh, N.B.; Partlow, W.D. Crystals for Ultraviolet Light Filters. U.S. Patent 5788765, 4 August 1998.

9. Rudneva, E.B.; Mamomenova, V.L.; Malakhova, L.F.; Voloshin, A.E.; Smirnova, T.N. Cs2Ni $\left(\mathrm{SO}_{4}\right)_{2} \cdot 6 \mathrm{H}_{2} \mathrm{O}$ (CNSH) crystal: Growth and some properties. Cryst. Rep. 2006, 51, 344-347. [CrossRef] 
10. Su, G.B.; Zhuang, X.X.; He, Y.P.; Li, Z.D.; Wang, G.F.; Li, G.H.; Huang, Z.X. A new single crystal of iron nickel sulfate twelve hydrate (FNSH) used as optical band pass filters. J. Cryst. Growth 2002, 243, 238-242. [CrossRef]

11. Wang, X.; Zhuang, X.X.; Su, G.B.; He, Y.P. A new ultraviolet filter: $\mathrm{Rb}_{2} \mathrm{Ni}\left(\mathrm{SO}_{4}\right)_{2} \cdot 6 \mathrm{H}_{2} \mathrm{O}(\mathrm{RNSH})$ single crystal. Opt. Mater. 2008, 31, 233-236. [CrossRef]

12. Su, G.B.; Zhuang, X.X.; He, Y.P.; Zheng, G.Z. A new crystal of ammonium cobalt nickel sulfate hexahydrate for UV light band-pass filter. Opt. Mater. 2008, 30, 916-919. [CrossRef]

13. Zhuang, X.X.; Su, G.B.; He, Y.P.; Zheng, G.Z. Growth and characterization of potassium cobalt nickel sulfate hexahydrate for UV light filters. Cryst. Res. Technol. 2006, 41, 1031-1035. [CrossRef]

14. Vanitha, D.; Kumar, S.S.; Athimoolam, S.; Bahadur, S.A. Growth and characterization of $\mathrm{K}_{2} \mathrm{Zn}_{\mathrm{x}} \mathrm{Ni}_{1-\mathrm{x}}\left(\mathrm{SO}_{4}\right)_{2} \cdot 6 \mathrm{H}_{2} \mathrm{O}$ mixed crystals for UV filters. Optik 2015, 126, 4553-4556. [CrossRef]

15. Silambarasan, A.; Rajesh, P.; Ramasamy, P. Study on structural, morphological, optical and thermal propertiesof guanidine carbonate doped nickel sulfate hexahydrate crystal. Spectrochim. Acta Part A 2015, 134, 345-349. [CrossRef] [PubMed]

16. Meena, K.; Bhagavannarayana, G.; Mojumdar, S.C. Urea/thiourea induced crystal growth of ammonium nickel sulfate hexahydrate and characterization studies. J. Therm. Anal. Calorim. 2015, 119, 963-968. [CrossRef]

17. Gao, S.M.; Xu, Z.H.; Ye, L.W.; Su, G.B.; Zhuang, X.X. Synthesis, crystal structure and properties of a coordination compound: $\mathrm{Ni}\left(\mathrm{C}_{6} \mathrm{H}_{12} \mathrm{~N}_{4}\right)_{2} \mathrm{SO}_{4} \cdot 4 \mathrm{H}_{2} \mathrm{O}$. Chin. J. Struct. Chem. 2015, 34, 1682-1688.

18. Nardelli, M.; Coghi, L. Bivalent metal sulfates hexacoördinated with methylurea. Gazz. Chim. Ital. 1958, 88, 355-358.

19. Nardelli, M.; Coghi, L. Complexes of bivalent metals with organic molecules containing oxygen (formamide, acetamide, methylurea). Ric. Sci. 1959, 29, 134-138.

20. Dolomanov, O.V.; Bourhis, L.J.; Gildea, R.J.; Howard, J.A.K.; Puschmann, H. OLEX2: A complete structure solution, refinement and analysis program. J. Appl. Cryst. 2009, 42, 339-341. [CrossRef]

21. Sheldrick, G.M. Crystal structure refinement with SHELXL. Acta Cryst. 2015, C71, 3-8.

22. Burton, W.K.; Cabrera, N.; Frank, F.C. The growth of crystals and the equilibrium structure of their surfaces. Philos. Trans. R. Soc. Lond. A 1951, 243, 299-358. [CrossRef]

23. Kossel, W. Über Krystall wachstum. Sci. Nat. 1930, 18, 901-910. [CrossRef]

24. Chernov, A.A. Formation of crystals in solutions. Contemp. Phys. 1989, 30, 251-276. [CrossRef] 